\title{
HAS INTERNATIONAL BORROWING OR LENDING DRIVEN AUSTRALIA'S NET CAPITAL INFLOW?
}

\author{
Anthony J. Makin* \\ Professor of Economics \\ Economics, Griffith Business School \\ Griffith University, Gold Coast 4222 \\ Australia \\ t.makin@griffith.edu.au \\ Paresh Kumar Narayan \\ Professor of Finance \\ University, Burwood 3125 \\ Australia \\ paresh.narayan@deakin.edu.au
}

Financial Econometrics Group, School of Accounting, Economics and Finance, Deakin

*corresponding author 


\title{
HAS INTERNATIONAL BORROWING OR LENDING DRIVEN AUSTRALIA'S NET CAPITAL INFLOW?
}

\begin{abstract}
Over recent decades the most significant global imbalances have been between Asia-Pacific economies, with most attention directed to the imbalances of the largest economies, China, Japan and the United States. In contrast, this paper examines how external account imbalances and real long term interest rates are determined in smaller open economies. It first derives the proposition that external imbalances and long term interest rates move together whenever saving-investment shocks are predominantly domestically sourced, but move oppositely when saving-investment shocks mainly emanate abroad. It then shows that in the case of Australia, an Asia-Pacific economy that has borrowed heavily from abroad since the mid 1980's, rising net capital inflow has had a statistically significant negative impact on domestic real interest rates. This suggests that over that time net international lending rather than net foreign borrowing was mainly responsible for the variation in its external imbalance and real interest rates.
\end{abstract}

Keywords: $\quad$ saving, investment, international borrowing and lending, Australia, interest rates

JEL: $\quad F 15, F 30, F 34$ 


\section{Introduction}

Since the 1990s the current account imbalances of many advanced and emerging economies have risen sharply as a proportion of GDP. Financial liberalization has enhanced international capital mobility and facilitated a global de-linking of national saving and investment rates. Since the turn of the century, the most significant external account imbalances in the world have been in Asia-Pacific economies. Within Asia, China, Japan and other East Asian economies have experienced large current account surpluses, while in the Pacific, the United States, Australia and New Zealand have experienced long-running external deficits.

China's large current account surplus and the current account deficit of the United States have been extensively analysed in recent literature (see for example Blanchard, Giavazzi and Sa 2005, Goldstein and Lardy 2006, Makin 2007, Truman 2005, Ventura 2001 and Xafa 2007). However, little attention has been paid to smaller economies in the Asia-Pacific region with persistently large external imbalances. Moreover, studies aimed at identifying the likely determinants of external surpluses and deficits have focused more on the domestic factors giving rise to higher borrowing, such as saving rates and fiscal settings, than on foreign factors.

Relative to the size of its economy, Australia's current account deficit has been one of the largest in the Asia-Pacific region, averaging 4.5 per cent of its GDP since international capital inflows and outflows were liberalized and its exchange rate floated in the mid 1980's. Australia's persistent borrowing has resulted in a net foreign debt level that stands at over 60 percent of GDP, also making it one of the world's biggest international debtors for its size. 
Hitherto, the expansive literature on the theory of international borrowing and lending (see for instance Frenkel and Razin 1987, Obstsfeld and Rogoff 1995, 1996, Razin 1995, Sachs 1981, Kraay and Ventura 2000) relies heavily on intertemporal precepts and usually assumes the supply of foreign funds is infinitely elastic at a given real world interest rate. This approach, also termed the present value model of the current account, usually assumes the current account balance reflects optimizing forward-looking decision-making by agents' about consumption. If agents' expect the national cash flow in the future to rise, increased current consumption (or lower saving) will be reflected in a larger current account deficit, in the spirit of Friedman's (1957) permanent income hypothesis. In other words, it suggests an economy's net foreign borrowing reflects intertemporal consumption smoothing by domestic residents.

Building on Sheffrin and Woo (1990), empirical adaptations of this approach by Cashin and McDermott (2002) and Otto (2003) help explain the significance and sustainability of Australia's current account deficits over recent decades; Kim, Hall and Buckle (2006) similarly explain New Zealand's current account deficit experience. They provide evidence that conditions for intertemporal solvency have generally been met in these economies and that their sizeable external deficits have hitherto not been cause for major policy concern.

Yet previous present value studies of Australia's current account, though useful, have sought to explain current account variation with reference to domestic residents' consumption behaviour only and have assumed a constant real, risk free, foreign interest rate over the data sample period. What has not been sufficiently recognized in models linking saving, investment and international capital flows is that an economy's net foreign borrowing may be predominantly 
influenced not by altered saving and investment behaviour at home, but by changed saving and investment abroad, as implied by Bernanke (2005). Identifying whether most of the variation in net capital inflow matching the external deficit is sourced at home or abroad has important implications for fiscal policy and domestic real interest rates.

Using Australia as a case study of a relatively small open economy facing an exogenous real world interest, this paper provides a new perspective on whether foreign borrowing or lending primarily influences the external imbalance, or net capital inflow, and real domestic interest rate. It is structured as follows. Section 2 introduces a novel flow of funds framework for interpreting links between saving, investment, international borrowing, lending and real interest rates by

considering the case of a small borrower economy facing an interest risk premia. Section 3 outlines the econometric approach used to test whether domestic or foreign factors have accounted for most of the variation in Australia's external imbalance and real interest rate. The final section concludes with a summary of results and discussion of policy implications.

\section{Saving, Investment and the External Imbalance}

In light of the limitations with previous present value studies of Australia's current account imbalance, the alternative model developed in what follows is based on a flow of funds approach to the current account which, unlike earlier studies, allows for period to period variation in real interest rates (inclusive of a risk premium), domestic saving, domestic investment, and in saving and investment in the rest of the world. In this way, for the first time we focus on whether domestic or external factors are the predominant responsible for the variation in Australia's current account imbalance. 


\subsection{An International Borrowing and Lending Framework}

The following flow of funds relationships provide the foundations for linking saving, investment and the external imbalance for Australia (the home country) with international borrowing and lending from the rest of the world. It is possible to elaborate these relations with microfoundations, but these would detract from the international flow of funds focus and have no bearing on the theoretical and empirical results to follow.

$$
\begin{aligned}
& S_{p}=Y-T-C_{p} \\
& S_{g}=T-C_{g} \\
& S=S_{p}+S_{g}=S\left(\stackrel{+}{r} ; C_{p}^{-}, \bar{C}_{g}\right) \\
& I=I_{p}+I_{g}=I\left(\stackrel{+}{r} \dot{q}, I_{g}^{+}\right) \\
& I-S=K A S=B^{*}\left(\stackrel{-}{r} ; \stackrel{+}{C}_{p}^{+}, \stackrel{+}{q}, \stackrel{+}{I}_{g}, \stackrel{+}{C}_{g}\right)
\end{aligned}
$$

where

$S_{p}$ is private saving

$r$ is the real domestic interest rate

$Y$ is national income, net of income paid abroad

$T$ is government tax revenue

$C_{p}$ is household consumption

$S_{g}$ is public saving

$C_{g}$ is public consumption

$S$ is total domestic saving

$I_{p}$ is private investment 
$I_{g}$ is public investment

$q$ is the ratio of the market value of private capital to its replacement cost

$K A S$ is the capital account surplus

$B^{*}$ is the external borrowing requirement

Relations (1) to (3) define private and public saving, with private saving determined as a residual between national income and household consumption. Public saving is the difference between government consumption and revenue. Although the Ricardian Equivalence proposition implies that policy-induced changes in public saving can induce an offset in private saving if households anticipate increased future taxes, empirical evidence suggests the offset is well under unity. ${ }^{1}$ Hence, in net terms a rise in $C_{g}$ reduces public saving and national saving.

The demand for funds derives from private and public investment demand (equation (4)). Private investment is positively related to the ratio of the market value of capital to its replacement cost after Tobin's (1969) $q$ theory, and negatively related to the real interest rate. Equation (5) shows that a capital account surplus, or net foreign borrowing, funds domestic investment beyond the level of domestic saving.

For borrower countries, the rest of the world acts as a lender of surplus saving over investment. Assuming the same basic factors determine saving and investment abroad as at home, it follows

that $\quad S^{*}-I^{*}=C A S^{*}=L^{*}\left(r^{*} ; C_{p}^{-}, q^{*}, \bar{I}_{g}^{*}, \bar{C}_{g}^{*}\right)$

where asterisks denote the foreign counterparts of the variables defined above and

${ }^{1}$ See Seater (1993), Masson, Bayoumi, and Hossein (1998), Gale and Orszag (2004) and Ricciutti (2003). 
$C A S^{*}$ is the rest of the world's current account surplus against the home country

$L^{*}$ is lending to the home country

$r^{*}$ is the real world interest rate

A common real interest rate equilibrates the quantum of international borrowing and lending to the home country over any given period. If the home country is too small to affect the world interest rate and if the rest of the world becomes increasingly averse to lending to it as foreign debt rises, then

$$
r=r^{*}+\rho\left(\stackrel{+}{F^{*}} ; \stackrel{+}{R}\right)
$$

where

$\rho$ is the risk premium above the world interest rate

$F^{*}$ is the stock of foreign debt and

$R$ captures other risk factors such as exchange rate risk and country risk.

Static exchange rate expectations are assumed as the normal case in the absence of any consensus about the short to medium term determinants of the exchange rate.

These relationships are graphically depicted in loanable funds - real interest rate space, as shown in the left panel of Figure 1, which significantly extends the standard treatment of international borrowing to incorporate lending behavior inclusive of risk aversion. The downward sloping schedule conventionally shows the domestic demand for funds arising for net investment while the upward sloping schedule depicts net saving or the supply of domestic funds.

The net international borrowing requirement ex ante is shown as the horizontal distance between the demand for funds and the supply of domestic saving for a range of interest rates. The 
investment - saving gap is replicated by the $B_{0}^{*}$ schedule in the right panel drawn in real interest rate - international borrowing and lending space.

\section{Figure 1: International Borrowing, Lending and Real Interest Rates}

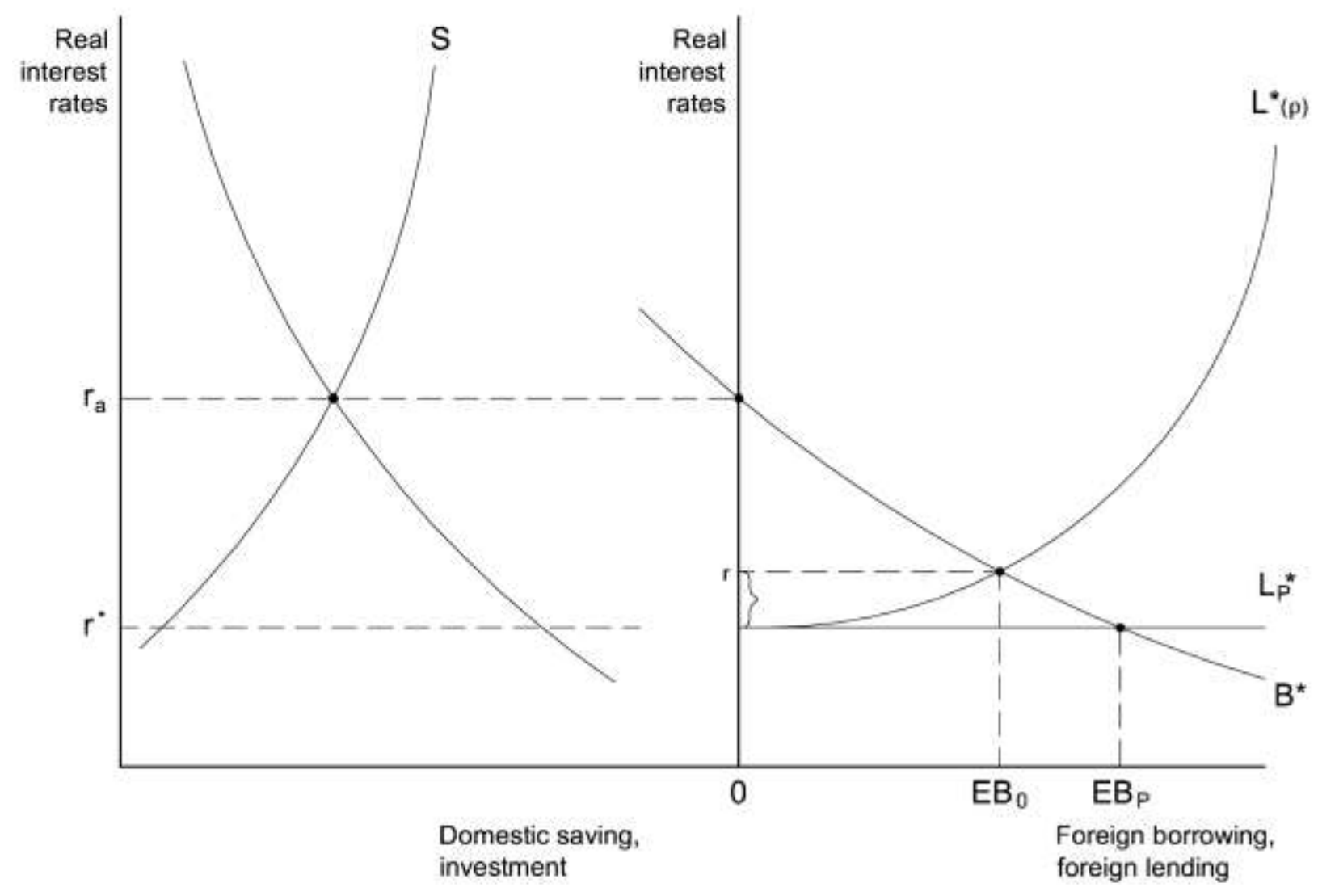

A rise in the economy's borrowing requirement, due for instance to increased real investment opportunities (a rise in $q$ ) or fall in public saving due to higher public consumption shifts the $B^{*}$ schedule rightward. Only if international capital mobility is perfect, will foreigners lend at $r^{*}$, the going world interest rate, as shown by the horizontal $L_{0}^{*}$ schedule. Yet, in reality capital 
mobility is not infinitely elastic and lenders are averse to default and other forms of risk, including currency depreciation. Hence, the supply of foreign funds the home country can borrow depends not only on the excess of global saving over investment, but on risk perceptions.

This explains the upward sloping foreign lending or net capital inflow schedule, $L^{*}$ in Figure 1. The more risk-averse foreign investors are to rising foreign debt, the steeper the slope of the $L^{*}$ schedule. Changes in world saving relative to investment affect real global interest rates and shift the $L^{*}$ schedule, downwards when net global saving rises, upwards when it falls. Other shift factors are expected appreciation/depreciation and heightened perceptions of political/country risk.

\subsection{Examining Domestic versus Foreign Net Saving Shocks}

This international borrowing and lending framework can now be used to predict the effect of various domestic and foreign saving and investment shocks on both the external imbalance and real interest rates as shown in Figure 2 based on the right panel of Figure 1. 


\section{Figure 2: Domestic vs Foreign Net Saving Shocks}

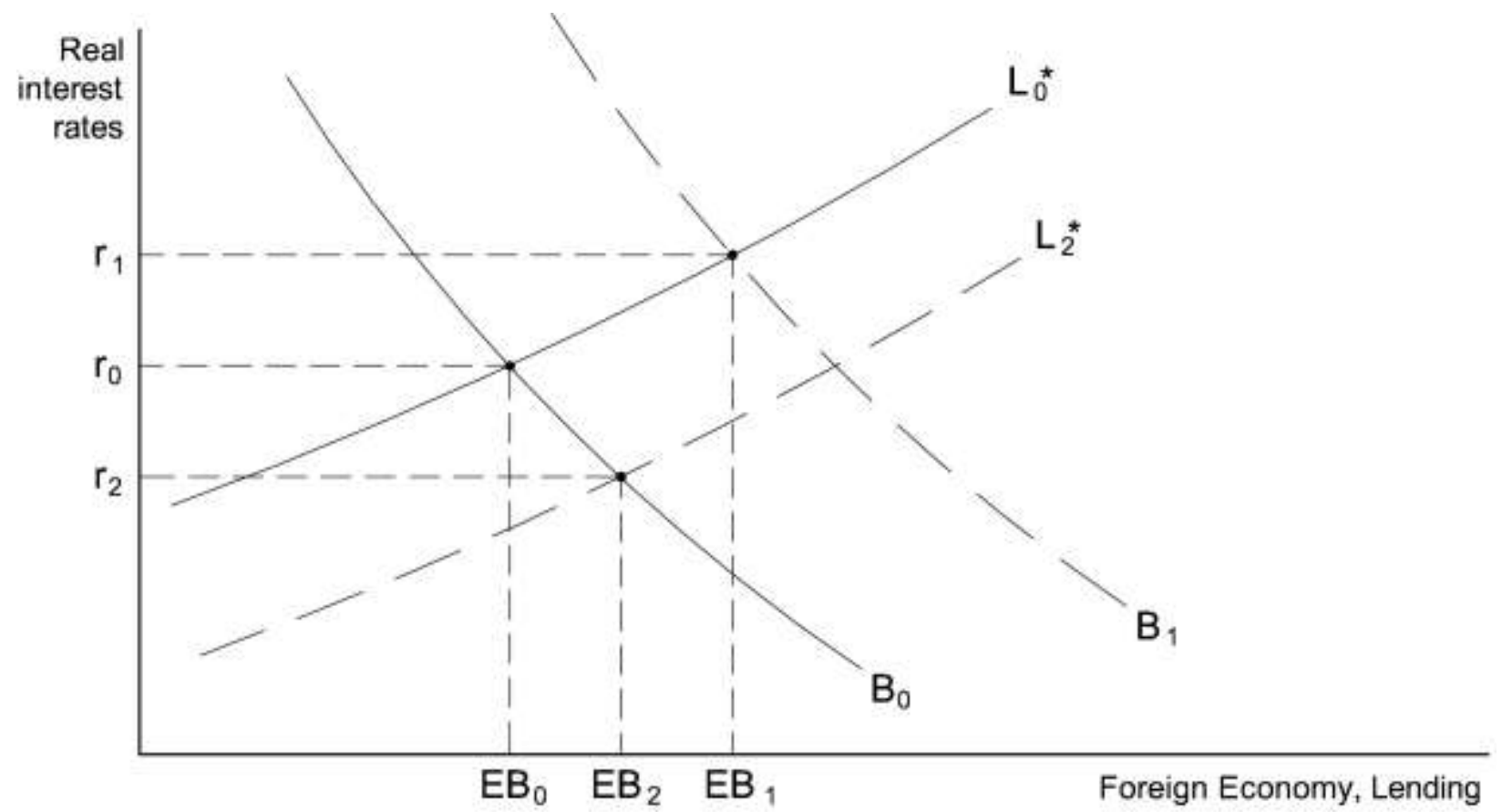

For instance, an increase in domestic investment spending due to an increase in $q$, other things the same, shifts the ex ante foreign borrowing schedule outward. The real domestic interest rate rises from $r_{0}$ to $r_{1}$ and the external surplus increases from $E B_{0}$ to $E B_{1}$ ex post. Likewise, a rise in public consumption or investment has the same effect. These cases exemplify domestically sourced shocks that simultaneously influence the external imbalance and real interest rates.

Yet, foreign saving and investment shocks emanating from abroad can also influence the home economy's external surplus and real interest rate. For instance, assume the same initial equilibrium as before (at $r_{0}, E B_{0}$ ) and that, other things equal, private investment overseas falls relative to private saving, raising net foreign saving. In this case, the world interest rate falls, the 
foreign lending schedule shifts down, the capital account surplus widens from $E B_{0}$ to $E B_{2}$ and the equilibrium interest rate falls from $r_{0}$ to $r_{2}$. Alternatively, with lower foreign public spending public saving abroad rises, the external surplus also widens and the real interest rate falls. In the contrary case of reduced net private or public saving abroad due to increased consumption or investment, the home economy's external surplus falls and real interest rate rises.

\section{Table 1 - Domestic, Foreign Net Saving, the External Surplus and the Real Interest Rate}

$\begin{array}{lll}\begin{array}{l}\text { Source of Net Saving } \\ \text { Shock: }\end{array} & \text { Effect on: } & \\ & \text { Capital Account Surplus } & \text { Real Interest Rate } \\ \text { Domestic } & & \\ & & \uparrow \\ \text { Private Saving } \downarrow & \uparrow & \uparrow \\ \text { Public Saving } \downarrow & \uparrow & \uparrow \\ \text { Private Investment } \uparrow & \uparrow & \uparrow \\ \text { Public Investment } \uparrow & \uparrow & \\ & & \\ \text { Foreign } & & \\ & & \downarrow \\ \text { Private Saving } \uparrow & \uparrow & \downarrow \\ \text { Public Saving } \uparrow & \uparrow & \downarrow \\ \text { Private Investment } \downarrow & \uparrow & \downarrow \\ \text { Public Investment } \downarrow & \uparrow & \end{array}$

Table 1 presents all possible saving and investment shocks (domestic and foreign) that increase the external imbalance and vary real interest rates. The interesting general result that emerges is this: If the predominant net saving shock is domestic, the external imbalance and real interest rate move in the same direction, whereas if the predominant net saving shock is foreign, they move oppositely. This central finding makes it possible to identify whether domestic or foreign 
factors have mainly influenced Australia's external imbalance over recent decades. In other words, the external imbalance and real interest rate are positively related if the predominant shock is domestic, and negatively related if the predominant shock is foreign. This finding allows us to test whether foreign borrowing or lending has mainly influenced Australia's net capital inflow since the mid 1980's. Of course over a given period the international borrowing or lending schedules may both shift, in which case the general result holds for net movements in the schedules and so avoids any identification or simultaneity problem.

Following the theoretical framework outlined above, the estimable model for examining comovement or otherwise of real interest rates and external imbalances has the following form:

$$
r_{t}=\alpha_{0}+\alpha_{1} \operatorname{KAS}_{t}+\varepsilon_{t}
$$

Here, $\mathrm{r}$ is the equilibrium real domestic interest rate. Since we are interested in the long-term interest rate, we proxy this interest rate with the inflation-indexed government bond rate. $K A S$ is the external imbalance or capital account surplus, defined as a percentage of gross domestic product.

\section{Data, Model and Results}

\subsection{Data and preliminary features of the data}

In this section, we provide a description of our dataset. We use quarterly data for the period 1986Q3 to 2006Q2 and we avoid the tumultuous period of the global financial crisis of 2008-10. The real interest rate ( $r$ ) series is derived by averaging monthly rates on inflation indexed Treasury bonds as published online by the Reserve Bank of Australia (RBA) (RBA Statistics 
Table F2). The current account deficit, or equivalently the capital account surplus (KAS), is expressed as a percentage of GDP and based on data published by the Australian Bureau of Statistics (ABS) (ABS Catalogues 5206.0 and 5302.0).

A plot of the data series is provided in Figure 3. Four features of the data series are rather obvious. First, they have different trends in the sense that the real interest rate is downward sloping (suggesting a negative trend) and the current account imbalance has a upward trend (suggesting a positive trend). Second, the real interest rate has a smooth but steady decline in the post-1994 period compared to a cyclical behavior in the pre-1994 period. Third, the current account imbalance series exhibits more variations and a few spikes are visible, one in 1989, followed by 1994, 1996, and 2001. Fourth, both series look stationary. We will later confirm the integrational property of the data series statistically.

Next, we report some common descriptive statistics in Table 2. We find that the mean real interest rate over the period $1986 \mathrm{Q} 3$ to $2006 \mathrm{Q} 2$ was 4.16 percent, while the mean current account imbalance was around 3.49 percent. Based on the coefficient of variation, the interest rate series turns out to be relatively more volatile. Finally, we apply the Jarque-Bera test to examine whether the series is normally distributed. The null hypothesis is that the series is normally distributed. We cannot reject the null hypothesis, implying that both series have a normal distribution. A final investigation relates to the endogeneity of the KAS. We test this by simply regressing the error term obtained from an OLS regression model of Equation (9) on the first difference of the KAS variable. The coefficient turns out to be 0.1653 with a t-test statistic of 1.4710. This implies that KAS is not endogeneous. 
Table 2: Some descriptive statistics

\begin{tabular}{|l|c|c|}
\hline & r & KAS \\
\hline Mean & 4.169 & 3.488 \\
\hline Median & 4.215 & 3.455 \\
\hline Maximum & 5.660 & 6.620 \\
\hline Minimum & 2.230 & 1.350 \\
\hline Std. Dev. & 0.930 & 1.339 \\
\hline & 3.779 & 4.309 \\
Jarque-Bera(JB) & $(0.151)$ & $(0.116)$ \\
\hline
\end{tabular}

Note: the probability value for the JB test is given in parenthesis.

Figure 3: A plot of the data series

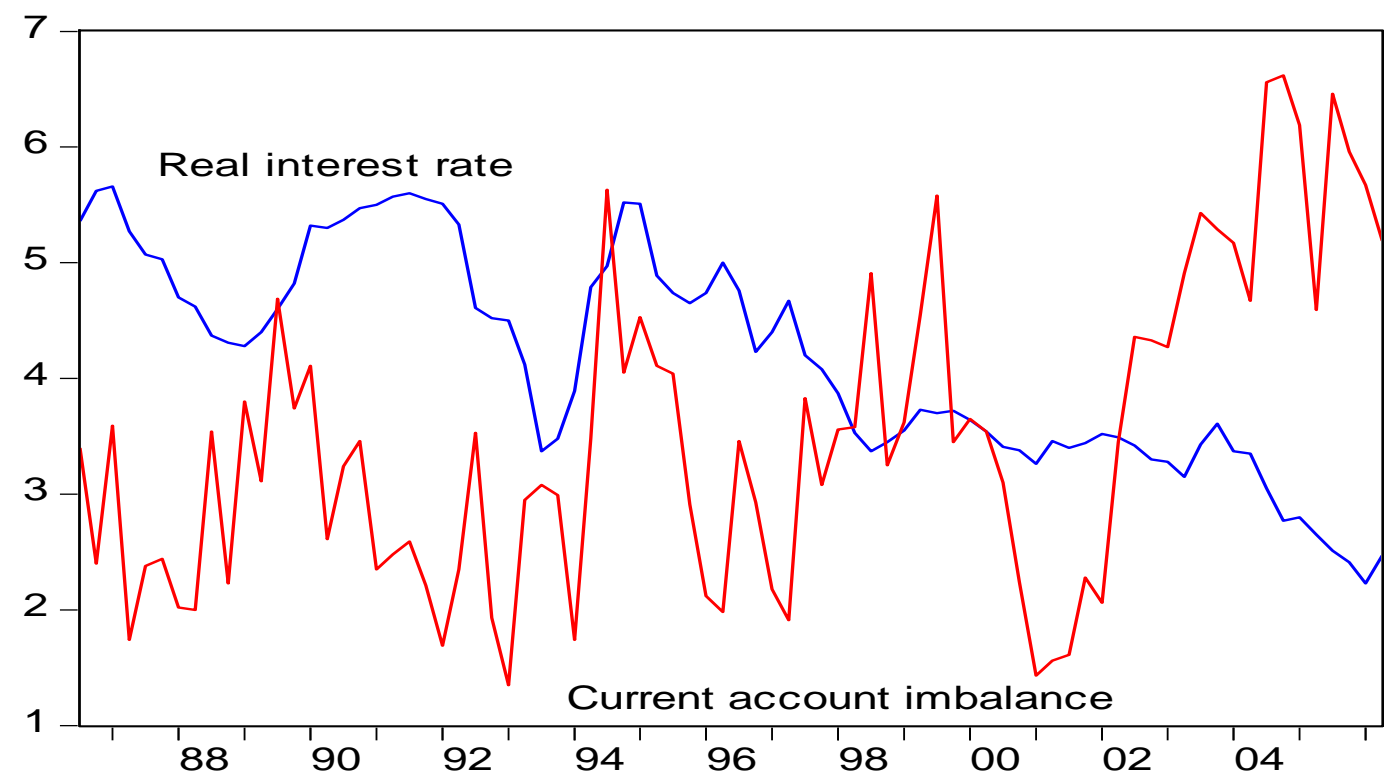

We first conduct tests for the integrational properties of real domestic interest rate and current account balance as a percentage of GDP. We use a battery of tests, namely the ADF, PP, ADFGLS and the KPSS tests. The first three tests examine the null of non-stationarity against mean and trend stationarity, while the KPSS test examines the null hypothesis of stationarity against 
the alternative that the series contains a unit root. The ADF-GLS is an extension of the ADF test based on the generalized least squares (GLS) estimator, while the PP test is similar to the ADF test with the difference that it uses a bandwidth as opposed to lag length in controlling for serial correlation.

The results are reported in Table 3. We find that there is mixed evidence on the integrational properties of the two variables. In sum, our results from unit root and stationarity tests are as follows. For the interest rate variable, there is evidence from all four tests of non-stationarity when we do not allow for a time trend. However, when we include a time trend, three of the four tests suggest that real interest rate is trend stationary. For the current account balance series, we find that three of the four tests suggest that it is non-stationary when we do not allow a time trend, while three of the four tests suggest stationarity when we allow a time trend.

In the next step, we run an OLS regression based on the regression model captured by equation (9). The idea behind this exercise was to examine whether the OLS model consisted of ARCH effects. We found the ARCH (1), (2), (3) and (4) having an LM statistic of 57.17, 28.39, 21.48, and 19.54, respectively. In all the four cases, we obtained a p-value of zero, implying that we could not reject the null hypothesis of "no ARCH" effects. Thus, it is clear that the OLS regression model depicted by equation (9) suffers from ARCH. 
Table 3: Tests for unit root and stationarity

\begin{tabular}{lllllllll}
\hline & ADF & \multicolumn{2}{c}{ PP } & \multicolumn{3}{l}{ ADF-GLS } \\
\hline & NT & T & NT & T & NT & T & NT & T \\
\hline $\mathrm{r}$ & $-2.78[1]$ & $-3.51[1]$ & $-1.21[2]$ & $-2.92[3]$ & $-0.98[1]$ & $-3.55[1]$ & $1.07[6]$ & $0.09[6]$ \\
& $(-2.90)$ & $(-3.47)$ & $(-2.89)$ & $(-3.47)$ & $(-1.95)$ & $(-3.10)$ & $(0.46)$ & $(0.15)$ \\
\hline \multirow{2}{*}{ KAS } & $-2.33[4]$ & $-3.66[5]$ & $-3.14[2]$ & $-4.33[0]$ & $-2.40[4]$ & $-2.98[4]$ & $0.55[6]$ & $0.11[6]$ \\
& $(-2.90)$ & $(-3.47)$ & $(-2.89)$ & $(-3.47)$ & $(-1.95)$ & $(-3.10)$ & $(0.46)$ & $(0.15)$ \\
\hline
\end{tabular}

Notes: For the ADF and ADF-GLS tests, the square brackets contain the lag lengths, while for the PP and KPSS tests, the square brackets contain the selected bandwidths. In parenthesis is the test statistics. Finally, NT and T denote no trend and trend models, respectively.

\section{2. $\quad$ Model}

To remedy ARCH effects, we employ the EGARCH model proposed by Nelson (1991). We assume a conditional normal distribution and specify an $\operatorname{EGARCH}(1,1)$ model with the following mean and variance structures:

Mean equation:

$r_{t}=c+\beta K A S+\varepsilon_{t}$

Variance equation:

$\log \left(\sigma_{t}^{2}\right)=\omega+\alpha\left(\left|\frac{\varepsilon_{t-1}}{\sigma_{t-1}}\right|-\sqrt{\frac{2}{\delta}}\right)+\gamma \frac{\varepsilon_{t-1}}{\sigma_{t-1}}+\beta \log \left(\sigma_{t-1}^{2}\right)$

There are four reasons for our choice of the EGARCH model over other financial volatility models, including the GARCH model. We briefly summarise our motivation for choosing the EGARCH model. First, one appealing feature of the EGARCH model is that it does not impose any restrictions on $\alpha, \gamma$, and $\beta$ on their impact on sigma, the variance of the interest rate series. Second, EGARCH model is flexible to the extent that it allows for oscillatory behaviour in the conditional variance; that is, the $\beta$ coefficient can be either negative or positive. The estimate of 
$\beta$ allows one to evaluate whether shocks to the variance are persistent or not. Nelson (1991) shows that $|\beta|<1$ ensures stationarity and ergodicity for the $\operatorname{EGARCH}(1,1)$.

Third, the EGARCH model is flexible enough to allows us to distinguish between symmetric and asymmetric volatility, which is captured by the parameter $\gamma$. If $\gamma>0$, the implication is that positive shocks give rise to higher volatility than negative shocks, and vice versa. Fourth, the parameter $\alpha$ represents the magnitude of the conditional shock on the conditional variance.

Our approach is to estimate three variants of the EGARCH model specified above. The first model is an EGARCH-M model, which essentially includes the variance of real interest rate in the mean equation. The second model is an EGARCH-ARMA model, which essentially includes the autoregressive moving average components in the mean equation. The final model is the EGARCH-ARMA-M, which in addition to the ARMA terms also includes the variance of the real interest rate variable in the mean equation. We believe that estimating multiple regression models is crucial in order to examine the robustness of our results.

The Bollerslev and Wooldridge (1992) procedure is applied to compute robust standard errors. We estimate the models using the maximum likelihood estimation technique, assuming normally distributed errors and the optimal lag lengths are selected using the Schwarz Bayesian Criterion (Schwartz, 1978).

\subsection{Results}

The results from the EGARCH model are reported in Table 4. The results are organised as follows. Column 2 contains results from the basic EGARCH model, column 3 reports results 
from the mean-EGARCH model, column 4 contains results from the EGARCH model where the mean equation is augmented with the ARMA components, while the final column reports results from the EGARCH-ARMA model but augmented with the $\log (\mathrm{GARCH})$ variable in the mean equation. In other words, columns 3 and 5 test whether the mean interest rate is affected by volatility in the real interest rate. The last four rows contain the ARCH diagnostic test, which examines the null hypothesis of 'no GARCH' effect in the estimated EGARCH models.

Table 4: EGARCH results

\begin{tabular}{|c|c|c|c|c|}
\hline \multirow{2}{*}{ Constant } & Model 1 & Model 2 & Model 3 & Model 4 \\
\hline & $\begin{array}{c}5.1817 * * * \\
(0.2034)\end{array}$ & $\begin{array}{c}5.4878 * * * \\
(0.1701)\end{array}$ & $\begin{array}{c}4.1133 * * * \\
(0.2449)\end{array}$ & $\begin{array}{c}4.8552 * * * \\
(0.1555)\end{array}$ \\
\hline KAS & $\begin{array}{c}-0.3248 * * * \\
(0.0502)\end{array}$ & $\begin{array}{c}-0.1026 * * * \\
(0.0388)\end{array}$ & $\begin{array}{c}-0.1113 * * * \\
(0.0409)\end{array}$ & $\begin{array}{c}-0.1295 * * * \\
(0.0257)\end{array}$ \\
\hline $\log (\mathrm{GARCH})$ & - & $\begin{array}{c}0.5634 * * * \\
(0.0863)\end{array}$ & - & $\begin{array}{c}0.2616 * * * \\
(0.0399)\end{array}$ \\
\hline $\operatorname{AR}(4)$ & - & - & $\begin{array}{c}0.5867 * * * \\
(0.0813)\end{array}$ & $\begin{array}{c}0.1406 \\
(0.2279)\end{array}$ \\
\hline MA(4) & - & - & $\begin{array}{l}-0.0299 \\
(0.1131)\end{array}$ & $\begin{array}{c}0.1325 \\
(0.2557)\end{array}$ \\
\hline$\omega$ & $\begin{array}{l}-1.2810 * \\
(0.0502)\end{array}$ & $\begin{array}{c}-0.7083 * * * \\
(0.2120)\end{array}$ & $\begin{array}{c}-1.8252 * * * \\
(0.6129)\end{array}$ & $\begin{array}{c}-1.0893 * * * \\
(0.1630)\end{array}$ \\
\hline$\alpha$ & $\begin{array}{c}1.1600 \\
(0.7296)\end{array}$ & $\begin{array}{c}0.2824 * * * \\
(0.0676)\end{array}$ & $\begin{array}{l}1.4092 * * \\
(0.5655)\end{array}$ & $\begin{array}{c}0.6626 * * * \\
(0.0392)\end{array}$ \\
\hline$\gamma$ & $\begin{array}{l}-0.0026 \\
(0.2929)\end{array}$ & $\begin{array}{c}0.5004 * * * \\
(0.0756)\end{array}$ & $\begin{array}{c}0.0295 \\
(0.2609)\end{array}$ & $\begin{array}{c}0.5054 * * * \\
(0.1038)\end{array}$ \\
\hline$\beta$ & $\begin{array}{c}0.6455 * * \\
(0.3419)\end{array}$ & $\begin{array}{c}0.8043 * * * \\
(0.0641)\end{array}$ & $\begin{array}{c}0.6118 * * * \\
(0.2206)\end{array}$ & $\begin{array}{c}0.8923 * * * \\
(0.0355)\end{array}$ \\
\hline \multicolumn{5}{|l|}{ Diagnostic test } \\
\hline$\overline{\mathrm{R}}^{2}$ & 0.1591 & 0.8259 & 0.4477 & 0.6601 \\
\hline $\mathrm{ARCH}(1)$ & $\begin{array}{c}0.1975 \\
(0.6579)\end{array}$ & $\begin{array}{c}0.0086 \\
(0.9263)\end{array}$ & $\begin{array}{c}0.7008 \\
(0.4053)\end{array}$ & $\begin{array}{c}0.2839 \\
(0.5958)\end{array}$ \\
\hline $\mathrm{ARCH}(2)$ & $\begin{array}{c}1.4743 \\
(0.2355)\end{array}$ & $\begin{array}{c}1.0064 \\
(0.3704)\end{array}$ & $\begin{array}{c}0.3644 \\
(0.6959)\end{array}$ & $\begin{array}{c}0.0233 \\
(0.9769)\end{array}$ \\
\hline $\mathrm{ARCH}(3)$ & $\begin{array}{c}0.9459 \\
(0.4230)\end{array}$ & $\begin{array}{c}1.7873 \\
(0.1571)\end{array}$ & $\begin{array}{c}0.4495 \\
(0.7184)\end{array}$ & $\begin{array}{c}0.1858 \\
(0.9057)\end{array}$ \\
\hline $\mathrm{ARCH}(4)$ & $\begin{array}{c}1.0643 \\
(0.3806)\end{array}$ & $\begin{array}{c}2.5091 \\
(0.0516)\end{array}$ & $\begin{array}{c}0.7863 \\
(0.5381)\end{array}$ & $\begin{array}{c}0.0887 \\
(0.9856)\end{array}$ \\
\hline
\end{tabular}

Notes: The standard errors are in parenthesis except for the results on diagnostic tests; for the diagnostic tests the probability values are in parenthesis. $*(* *) * * *$ denote statistical significance at the 10 per cent, 5 per cent, and 1 per cent levels, respectively. 
The main focus of our results from the EGARCH model is based on the estimate of KAS. Given our aim, to examine whether internal or external factors determine Australia's long-term interest rate and the current account imbalances, the application of more than one model is crucial because it allows us to ascertain the robustness of the results. We find fairly robust results on the impact of the current account imbalance on the real interest rate.

We find that the sign of the KAS variable is negative across all the four models and it is statistically significant at the 1 per cent level in all the four models. This result implies that a rise in current account balance reduces domestic real interest rate. That real interest rate and current account balances move in opposite directions suggests that external factors have been instrumental in determining Australia's current account balance.

From the point of view of gaining more insights on the relationship between real interest rate and current account imbalance, our modelling framework based on the EGARCH model has two advantages. One advantage is that the mean equation of the real interest rate allows us to examine whether volatility of long term real interest rate influences real interest rate. Two of our estimated models (models 2 and 4) examine this relationship. We find that interest rate volatility has a positive and statistically significant (at the 1 per cent level) effect on the long term real interest rate. The second advantage of the EGARCH model is rooted in the variance equation of the real interest rate, allowing us to better understand the behaviour of the volatility of real interest rate. 
Essentially, we are able to deduce whether or not shocks to interest rate volatility are persistence and asymmetric in nature. These are important pieces of information given our earlier finding that interest rate volatility raises interest rate. Gamma captures symmetric or otherwise of shocks to interest rate volatility while beta captures persistence or otherwise of shocks to interest rate volatility. Our main findings are as follows.

Based on models 2 and 4 which are mean-EGARCH models, evidence suggests that shocks have asymmetric effects on real interest rate volatility, while models 1 and 3 which do not model the impact of volatility in the mean equation, reveal that shocks are symmetric. An issue now is which model should we trust? One way of addressing this issue is to choose the model with the highest explanatory power.

Our results reveal that models 2 and 4 have the most explanatory power, so we conclude that shocks to interest rate volatility have asymmetric effects. The next issue is whether or not shocks have a persistent impact on interest rate volatility and whether the volatility is stationary. Again, based on models 2 and 4 which have most explanatory power, we find that shocks are highly persistent and volatility is stationary. The final issue is to examine whether our estimate models are free of ARCH. We report the ARCH LM test in the last 4 rows of Table 2. Our results suggest that we are unable to reject the null hypothesis of 'no ARCH' effects in all the four models, implying that our EGARCH models are well behaved. 


\subsection{A test of robustness}

As a robustness test, we re-estimate the model using the growth rate of the variables. The limitation of this approach needs to be acknowledged at the outset so that the results here can be interpreted cautiously. The main limitation is that, as confirmed by unit root tests with a time trend, both variables - current account imbalance and real interest rate - are stationary in their level form. It follows that taking their growth form will amount to twice differencing the data series. The impact of second differencing of the variables is obvious from the results reported in Table 5.

Notice that: (a) the magnitude of the impact of the current account imbalance has fallen substantially across all the four models, and (b) the adjusted R-squared of the model has also declined. These outcomes are a direct effect of twice differencing the variables. In other words, we took the growth rate of a stationary variable. Nonetheless, the objective, at the suggestion of a referee of this journal, was to examine if the effect of current account imbalance on real interest rate is robust. We do find robust results in the sense that in three of the four models, the current account imbalance had a statistically significant negative effect on the real interest rate. 
Table 5: EGARCH results from a model of the growth rates of the two variables

\begin{tabular}{|c|c|c|c|c|}
\hline & Model 1 & Model 2 & Model 3 & Model 4 \\
\hline \multirow[t]{2}{*}{ Constant } & -0.9329 & 8.6723 & $-0.8325^{* *}$ & $2.8836 * * *$ \\
\hline & $(0.5713)$ & $(5.9390)$ & $(0.3381)$ & $(0.8307)$ \\
\hline \multirow{2}{*}{ KAS } & -0.0123 & $-0.0414 * * *$ & $-0.0788 * * *$ & $-0.0609 * * *$ \\
\hline & $(0.0180)$ & $(0.0152)$ & $(0.0127)$ & $(0.0142)$ \\
\hline \multirow[t]{2}{*}{$\log (\mathrm{GARCH})$} & - & -0.2497 & - & -0.0582 \\
\hline & & $(0.2300)$ & & $(0.0746)$ \\
\hline \multirow[t]{2}{*}{$\mathrm{AR}(4)$} & - & - & -0.1219 & -0.0304 \\
\hline & & & $(0.2445)$ & $(0.3079)$ \\
\hline \multirow[t]{2}{*}{$\mathrm{MA}(4)$} & - & - & -0.2634 & -0.1375 \\
\hline & & & $(0.2414)$ & $(0.2877)$ \\
\hline \multirow[t]{2}{*}{$\omega$} & 0.2069 & $3.0735 * * *$ & $5.4301 * * *$ & $4.6809 * * *$ \\
\hline & $(0.3627)$ & $(1.0616)$ & $(1.9344)$ & $(1.6983)$ \\
\hline \multirow[t]{2}{*}{$\alpha$} & 0.3282 & -0.2119 & -0.8185 & -1.1613 \\
\hline & $(0.2741)$ & $(0.2019)$ & $(0.5299)$ & $(0.8234)$ \\
\hline \multirow[t]{2}{*}{$\gamma$} & -0.1835 & 0.1372 & -0.2421 & -0.8266 \\
\hline & $(0.1258)$ & $(0.1329)$ & $(0.3100)$ & $(0.5840)$ \\
\hline \multirow[t]{2}{*}{$\beta$} & $0.8748 * * *$ & 0.1966 & 0.3521 & 0.0090 \\
\hline & $(0.1374)$ & $(0.2518)$ & $(0.4571)$ & $(0.2144)$ \\
\hline \multicolumn{5}{|l|}{ Diagnostic test } \\
\hline$\overline{\mathrm{R}}^{2}$ & 0.0008 & 0.1044 & 0.0999 & 0.0974 \\
\hline \multirow[t]{2}{*}{$\mathrm{ARCH}(1)$} & 0.4362 & 0.0002 & 0.0827 & 14.111 \\
\hline & $(0.5110)$ & $(0.9897)$ & $(0.7745)$ & $(0.0003)$ \\
\hline \multirow[t]{2}{*}{$\mathrm{ARCH}(2)$} & 0.3602 & 0.1873 & 0.08702 & 8.0479 \\
\hline & $(0.6987)$ & $(0.8296)$ & $(0.9168)$ & $(0.0007)$ \\
\hline \multirow[t]{2}{*}{$\mathrm{ARCH}(3)$} & 0.2766 & 1.7292 & 1.8168 & 5.3417 \\
\hline & $(0.8421)$ & $(0.1686)$ & $(0.1523)$ & $(0.0023)$ \\
\hline \multirow{2}{*}{$\mathrm{ARCH}(4)$} & 1.1528 & 1.3939 & 1.3376 & 3.8935 \\
\hline & $(0.3391)$ & $(0.2450)$ & $(0.2653)$ & $(0.0067)$ \\
\hline
\end{tabular}

Notes: The standard errors are in parenthesis except for the results on diagnostic tests; for the diagnostic tests the probability values are in parenthesis. $*(* *) * * *$ denote statistical significance at the 10 per cent, 5 per cent, and 1 per cent levels, respectively. 


\section{Conclusion}

The phenomenon of growing external imbalances is often interpreted, in the spirit of Feldstein and Horioka (1980), as a weakening of the correlation between national saving and investment rates and hence a sign of increased international capital mobility. Although this perspective has generated a sizeable literature, the related question of whether economies' net capital inflows have varied primarily due to domestic or foreign factors, the main focus of this paper, has been largely neglected in comparison.

Australia has experienced the longest running external imbalance and highest net capital inflow relative to its size in the Asia-Pacific region, which is most often attributed to domestic factors that influence its national saving and investment behaviour. It provides an ideal case study for examining how internal and external factors influence net capital inflow in small open borrower economies facing a foreign debt related interest risk premium. The elements of this approach could be usefully applied to examining the experience of other relatively small borrower economies, regardless of their economic development level.

Using variants of EGARCH models we found evidence that net capital inflow has had a statistically significant negative impact on domestic real interest rates in Australia. This finding implies that foreign factors have primarily determined Australia's investment-saving imbalance. The EGARCH model also allows us to examine the dynamic characteristic of Australia's long term interest rate, showing that: (1) interest rate volatility has had a positive impact on interest rate; (2) shocks to interest rate volatility have asymmetric effects, meaning that positive and 
negative shocks exert different magnitudes of impact on the interest rate; and (3) that the impact of shocks on interest rate volatility are persistence, implying that shocks are long lasting.

The above findings have major economic policy implications. First, the result that Australia's external imbalance has been mainly determined by foreign rather than domestic factors suggests that Australia's long running external imbalance should not necessarily be a major macroeconomic policy concern per se since those foreign factors which help determine it lie beyond the control of domestic policymakers. Such factors include fiscal settings in major trading partners that vary their public saving and public investment levels, as well as the buoyancy of overall macroeconomic activity influencing trading partners' private investment spending relative to private saving.

Second, the results imply that fiscal measures undertaken by the Australian authorities to reduce the foreign borrowing requirement, may have no apparent impact on the external imbalance as intended, if simultaneously offset by foreign factors that raise in external lending. For instance, implementing fiscal austerity measures to reduce the external imbalance through public consumption or public investment spending cuts, or via changes to income tax and transfer payments aimed at raising private saving, may not seem to work if saving rises abroad, or investment falls at the same time.

Finally, the approach adopted above suggests that because the flow process of international and borrowing and lending determines medium to long domestic interest rates, as long recognised in the international macroeconomics literature, monetary policy, which operates primarily on short 
term interest rates, is unlikely to be an effective instrument for addressing external account imbalance problems.

\section{References}

Australian Bureau of Statistics (2010) Australian National Accounts, Catalogue 5206.0 Available at http://www.abs.gov.au/

Australian Bureau of Statistics (2010) Balance of Payments and International Investment Position, Australia, Catalogue 5302.0 Available at http://www.abs.gov.au/

Bernanke, B. (2005) "The Global Saving Glut and the U.S. Current Account Deficit", remarks by Governor Ben S. Bernanke at the Sandridge Lecture, Virginia Association of Economists, Richmond, Virginia, March 10.

Blanchard, O., Giavazzi, F. and Sa, F. (2005) “The U.S. Current Account and the Dollar”, NBER Working Paper N o. 11137.

Bollerslev, T., (1986) Generalised Autoregressive Conditional Heteroskedasticity, Journal of Econometrics, 31, 307-327.

Bollerslev, T., and Wooldridge, J.M., (1992) Quasi-maximum Likelihood Estimation and Inference in Dynamic Models with Time Varying Covariances, Econometric Reviews, 11, 14372.

Cashin, P. and McDermott, J. "Intertemporal Consumption Smoothing and Capital Mobility: Evidence from Australia," Australian Economic Papers, 2002, 41 (1), 82-98.

Deaton, A. (1992) Understanding Consumption, Oxford, Oxford University Press.

Engle, R.F., (1982) Autoregressive Conditional Heteroskedasticity with Estimates of the Variance of the UK Inflation, Econometrica, 50, 987-1008.

Feldstein, M. and Horioka, C. (1980) "Domestic Saving and International Capital Flows" Economic Journal, 90 (2):314-29.

Frenkel, J.and Razin, A. (1987) Fiscal Policies and the World Economy, Cambridge, Massachusetts: MIT Press.

Friedman, M. (1957) A Theory of the Consumption Function, Princeton University Press, New Jersey.

Gale, W. and Orszag, P. (2004) "Budget Deficits, National Saving and Interest Rates" Brookings Papers on Economic Activity, Brookings Institution, 2, 101-210. 
Ghosh, A. and Ostry, J (1995) "The Current Account in Developing Countries: A Perspective from the Consumption-Smoothing Approach". The World Bank Economic Review, 9: 305-334.

Goldstein, M. and Lardy, N. (2006) "China’s Exchange Rate Policy Dilemma” American Economic Review 96 (2), 422-426.

Kim, K., Hall V. and Buckle, R. (2006) "Consumption Smoothing in a Small, Cyclically Volatile Open Economy: Evidence from New Zealand". Journal of International Money and Finance 25(8):1277-1295

International Monetary Fund, (2007) World Economic Outlook, April, Washington, DC.

Kraay, A. and Ventura, J. (2000) "Current Accounts in Debtor and Creditor Countries" Quarterly Journal of Economics 115, 1137-1166.

Makin, A. (2007) “Does China’s Huge External Surplus Imply an Undervalued Yuan?” China and World Economy, 15(3), 89-102.

Makin, A. (2004) Global Finance and the Macroeconomy, Palgrave Macmillan, paperback edition, London \& New York.

Masson, P., Bayoumi, T. and Samiei, H. (1998) "International Evidence on the Determinants of Private Saving” World Bank Economic Review 12: 483 - 501.

McLeod, A.I., and Li, W.K., (1983) Diagnostic Checking ARMA Time Series Models Using Squared Residual Autocorrelations, Journal of Time Series Analysis, 4, 269-273.

Mercereau, B. and Miniane, J. (2004) "Challenging the Empirical Evidence from Present Value Models of the Current Account” IMF Working Paper WP/04/106 International Monetary Fund, Washington DC.

Nelson, D., (1991) Conditional Heteroskedasticity in Asset Returns: A New Approach, Econometrica, 59, 347-370.

Obstfeld, M. and Rogoff, K. (1996) Foundations of International Macroeconomics, MIT Press, Boston.

Obstfeld, M. and Kenneth R. (1995)"The Intertemporal Approach to the Current Account" in G. Grossman and K. Rogoff (eds.) Handbook of International Economics Volume 3, Elsevier: Amsterdam.

Otto, G. "Can an Intertemporal Model Explain Australia's Current Account Deficit?" Australian Economic Review, 2003, 36 (3), 350-359. 
Razin, A. (1995) "The Dynamic-Optimizing Approach to the Current Account: Theory and Evidence" in P. Kenen (ed). Understanding Interdependence: The Macroeconomics of the Open Economy, Princeton, NJ: Princeton University Press.

Reserve Bank of Australia (2010) Statistics Tables Available at http://www.rba.gov.au/statistics/

Ricciutti, R "Assessing Ricardian Equivalence" Journal of Economic Surveys (17, 1, 2003).

Sachs, J. (1981) "The Current Account and Macroeconomic Adjustment in the 1970's" Brookings Papers on Economics Activity, 1:201-282.

Seater, J. 1993. "Ricardian Equivalence.” Journal of Economic Literature, 31(1): 142-90.

Sheffrin, S. and Woo, W. (1990) "Present Value tests of an Intertemporal Model of the Current Account" Journal of International Economics 29, 237-253.

Tobin, J. (1969) “A General Equilibrium Approach to Monetary Theory" ournal of Money, Credit and Banking, 1:15-29.

Truman, E. (2005) “ Postponing Global Adjustment: An Analysis of the Pending Adjustment of Global Imbalances”, Institute for International Economics Working Paper No. 05-06.

Ventura, J. (2001) “A Portfolio View of the US Current Account Deficit” Brookings Papers on Economic Activity, 1, 241-253.

Xafa, M. (2007) “Global Imbalances: Do They Matter?” Cato Journal, 27 (1). 